\title{
Shiitisk politisk idétradition
}

Shiitiska rättslärda spelar en central roll i den politiska utvecklingen i Irak efter diktatorn Saddam Husseins fall. Utvecklingen efter den USA-ledda invasionen visar att de shiitiska rättslärdas förhållningssätt till den världsliga makten kan spåras tillbaka till ett beprövat handlingsmönster i shias historia. 
TEXT: Mohammad Fazlhashemi

EFTER DEN USA-LEDDA invasionen av Irak och Saddam Husseins fall trädde en rad shiitiska partier och grupperingar fram på den politiska kartan i Irak. Storayatollan Sistani och en rad andra shiitiska rättslärda har på olika sätt påverkat det politiska skeendet. Shiitiska partier och fraktioner har idag en majoritet i det irakiska parlamentet och besitter regeringsmakten.

Gemensamt för de olika religiöst inspirerade shiitiska aktörerna är att de hämtar inspiration ur en shiitisk politisk idétradition. De frågor som denna studie försöker besvara är följande:

Vad är det karaktäristiska för den shiitiska politiska idétraditionen? Hur har de shiitiska rättslärdas politiska ställningstaganden påverkats av invasionen? Går det att dra några historiska paralleller mellan den roll shiitiska rättslärda spelar idag och deras roll under liknande förhållanden i shias historia?

\section{Bakgrund}

Sedan den islamiska revolutionen i Iran I979 har shiitiska rättslärda som aktivt deltagit i den politiska processen varit ett välkänt fenomen. Det var då den shiitiska politiska doktrinen om de rättslärdas styre, velayat-e faqih, förvandlades till statsbärande ideologi. De shiitiska rättslärdas inblandning i politiken startade emellertid inte på I970-talet, utan kan spåras långt tillbaka i shias historia. Den allra tydligaste inblandningen sker under modern tid, det vill säga den tid då shiadominerade områden kommer i kontakt med europeiskt tankegods och konstitutionalismens idétradition vid mitten av i8oo-talet. En större aktivitet bland de shiitiska skriftlärda märks i samband med det osmanska rikets fall, europeiska och senare andra västerländska staters närvaro och inflytande i shiadominerade områden samt framväxten av etnochauvinistiska och nationalistiska ideologier som bathismen.

En överväldigande del av Iraks shiitiska befolkning tillhör tolvimamiterna, som utgår från föreställningen att ledarskapet efter profeten Muhammeds död skulle övergå till hans kusin Ali som var gift med profetens dotter Fatima och deras avkomma. Shiiterna manövrerades snabbt bort av den rivaliserande gruppen sunniterna och under de tolv shiitiska imamernas tid (633-880) hårdnade förtrycket mot shiiterna. Elva av imamerna mördades och den tolfte gick under jorden.

Enligt tolvimamiternas föreställningar inledde den siste shiitiske imamen alMahdi ett liv i fördoldhet efter en tid av underjordisk verksamhet på 880-talet. Tol- 
vimamiterna anser att al-Mahdi lever dold än idag och ska återkomma en dag för att befria världen från all ondska.

Föreställningen om al-Mahdis återkomst har format den tolvimamitiska politiska diskursen som en metahistorisk diskurs. ${ }^{.}$De rättslärda har emellertid använt denna diskurs på högst varierande sätt under olika sociopolitiska förhållanden och skilda tidsskeden. Under vissa perioder gavs den en ontologisk karaktär utan kopplingar till den politiska vardagen i syfte att försvara politisk kvietism, politisk overksamhet, samt utvecklandet av utopiska föreställningar om ett idealsamhälle som skulle upprättas vid den dolde imamens återkomst. De rättslärda gav uttryck för en politisk kvietism, som förordar stor återhållsamhet på gränsen till avvisande av inblandning i världslig politik. De utgick från föreställningen att makten de jure, enligt lagen, tillhörde den dolde imamen, men att den de facto, $i$ verkligheten, hamnat $i$ andras händer.

Under långa perioder har samma föreställning om den dolde imamen använts för att motivera ett slags politisk pragmatism och realism då man försiktigt utformade samarbetsformer för de shiitiska rättslärda och de världsliga makthavarna och tillät ett visst samröre dem emellan. Motivet bakom denna inställning var att man skulle göra det bästa av situationen i väntan på den dolde imamen. ${ }^{2}$

Föreställningarna om den dolde imamen har också använts i en revolutionär anda. Under shiaislams fjortonhundraåriga historia har denna revolutionära linje kommit upp till ytan då och då och periodvis trängt undan andra tolkningstraditioner. Det religiösa motivet bakom denna radikalisering har varit att i den tredje shii- tiske imamen Husseins anda inte ge efter för tyranniska härskare utan i stället ta strid mot dem. En annan tanke har varit att aktivt förbereda och påskynda den dolde imamens återkomst.

\section{Förändrade maktförhållanden}

Den kvietistiska riktningen kom att få ett stadigt grepp om den shiitiska politiska idétraditionen under stora delar av shias historia. En anledning tycks ha varit att den siste imamen al-Mahdis återkomst drog ut på tiden och man såg sig då nödsakad att anpassa sin politiska retorik efter de nya förhållandena. ${ }^{3}$

Kvietismens avhållsamhet från världslig makt ska ses i ljuset av den shiitiska minoritetens utsatta position under långa tider. Ledande shiitiska lärda såg kvietismen som enda utvägen för att skydda shiiternas från förföljelser.

Denna situation förändrades vid ett par tillfällen under ıooo-talet och vid mitten av I200-talet. Vid båda tillfällena förändrades maktförhållandena på ett sådant sätt att förföljelserna av shiiter avtog. På Iooo-talet tog den shiitiska furstesläkten buyiderna (934-I055) över makten i det abbasidiska kalifatet. Abbasiderna satt formellt kvar vid makten men den militära och politiska makten var i buyidernas händer. Den ändrade maktbalansen fick en direkt inverkan på de skriftlärdas syn i fråga om samröre med maktens företrädare. Under den här perioden framträdde en rad framstående shiitiska rättslärda som förordade en mer realpolitisk doktrin. De kunde exempelvis tänka sig att inneha världsliga ämbeten.

Ett tecken på de förändrade förhållandena ser vi hos den prominente shiitiske rättslärde Seyyed Murtada (937-IOI8), som skiljer mellan två sorters sultaner: de ond- 
sinta och de rättvisa. Han har inga betänkligheter mot att samarbeta eller tacka ja till befattningar som erbjuds av de rättvisa härskarna. För honom är deltagande i det politiska livet en förutsättning för att kunna genomdriva shias påbud. ${ }^{4}$

I mitten av Iooo-talet drevs buyiderna från makten och shiiterna hamnade återigen i en mycket utsatt position med följden att man återgick till den kvietistiska idétraditionen. ${ }^{5}$

Maktbalansen förändrades på nytt år I258 när mongolerna störtade det abbasidiska kalifatet. Buyidernas och mongolhärskarnas tid vid makten innebar att förtrycket mot shiiterna minskade. En del av dessa härskare ville dessutom arbeta för shiiternas bästa.

Under de nya politiska förhållandena och trots sin grundinställning om den dolde imamens irreversibla legala rätt till makten utvecklades föreställningen om att så länge den dolde imamen inte avbrutit sin tillvaro i fördoldhet kan man skilja mellan onda och goda världsliga härskare. De senare skulle man kunna ha goda relationer med och arbeta hos för att därigenom arbeta för shiiternas bästa. Det nya var att de shiitiska rättslärda till och med kunde tänka sig samarbete med icke-muslimska makthavare. Det tycks inte ha haft någon betydelse huruvida härskaren var muslim eller icke-muslim. ${ }^{6}$

\section{Shiitisk kungamakt}

Shiiternas situation förändrades på nytt vid safavidernas maktövertagande (I5OI-I736). Safaviderna utropade shia till statsreligion, eftersom den sufiorden som utgjorde det andliga ledarskapet för safaviderna hade övergått till shia på I400-talet. En annan och mer jordnära anledning var att safavi- derna behövde ett större folkligt stöd i kampen mot sina sunnitiska rivaler i väster, osmanerna, och i öster, uzbekerna. Det var en bedrift som safaviderna hoppades att de shiitiska rättslärda skulle bistå dem med genom sin välsignelse och genom sitt engagemang i delar av förvaltningen av riket. Genom sitt stöd till en av sunniterna förföljd religiös minoritet ville safaviderna bredda sin folkliga maktbas samt försäkra sig om de shiitiska lärdas lojalitet.?

Safavidernas maktövertagande förvandlade shiiterna från en förföljd religiös minoritet till en religiös gruppering med

\section{De centrala tankefigurerna i shiitisk politisk idéhistoria härrör från föreställningarna om den dolde imamen al-Mahdi.}

starka band till kungamakten. Den fråga som de shiitiska rättslärda ställdes inför var hur de skulle förhålla sig till safavidiska kungar, som med utgångspunkt från den ursprungliga shiitiska politiska doktrinen om synen på härskare under den dolde imamens frånvaro, per definition skulle betraktas som illegitima härskare. Dessa kungar var tvärt emot den dolde shiitiske imamen al-Mahdi inte fria från synd. Men de hade trots allt utropat shia till statsreligion i sitt stora rike och dessutom förbundit sig att arbeta för shiiternas bästa och försvara den mot sunniter. De shiitiska rättslärda ställdes inför en rad olika delikata problem. Bland annat ställdes frågan under vilka omständigheter de skulle legitimera kungarnas maktställning. Skulle de ställa några krav på kungarnas religiösa 
kunskaper nu när dessa skulle iklä sig rollen som shiitiska kungar? Var skulle man dra gränsen mellan kungamaktens och de rättslärdas maktbefogenheter och jurisdiktion? Skulle de rättslärda blanda sig i världsliga frågor eller begränsa sig till religiösa frågor och nöja sig med den nya rollen som den institution som skänkte den världsliga makten dess religiösa legitimitet.

\section{Avsaknad av politiska teorier}

Trots de förändrade förhållandena för shiitiska rättslärda visar en genomgång att politik och politisk teori inte hade någon självständig plats i tolvimamitiska shiitiska källor. Under de första sex århundradena i shias historia, från 800-talet fram till I500talet, återfinner man endast sporadiska spår av en debatt kring den världsliga styrelseformen. Det finns en grundföreställning som tar för givet att den världsliga makten skulle tillhöra den shiitiska imamen. I övrigt är diskussionen kring den världsliga makten inte särdeles utvecklad. ${ }^{8}$

Efter safavidernas maktövertagande tycks de shiitiska rättslärda ha godkänt en tågordning som innebar en uppdelning av uppgifterna i en religiös och en världslig avdelning. De religiösa frågorna, en rad sociala frågor och rättsliga frågor skulle skötas av de religiösa ledarna, medan härskarmakten skulle ta hand om övriga världsliga frågor. ${ }^{9}$

Det dröjer ända fram till I8oo-talets slut innan de shiitiska rättslärda utvecklar sina politiska teorier. Detta kan förklaras utifrån olika förklaringsmodeller:

I) De rättslärda hade färdigutvecklade politiska doktriner, men kunde inte ge uttryck för dessa på grund av det starka förtrycket från härskarmakterna. Medvetna om detta följde de den shiitiska traditionen taqiyya, förställning, och höll inne med sina teorier. De rättslärdas eftertryckliga vilja att behålla jurisdiktionen över rättsliga frågor och rättsapparaten var ett led i förarbetet till politiska doktriner. Ett väl fungerande rättssystem är en viktig förutsättning för politiskt herravälde. Som stöd för denna uppfattning påpekar man att kort efter safavidernas maktövertagande i Persien gav ett flertal rättslärda uttryck för sina politiska doktriner. ${ }^{\text {I }}$

2) Avsaknaden av politiska doktriner var ett uttryck för att de tidiga shiitiska rättslärda inte såg på politiken som en del av de

\section{De ledande rättslärda såg på den iranska modellen som en avvikelse från den klassiske traditionen.}

rättslärdas jurisdiktion. De begränsade sig till rättens och de vardagliga frågornas område. Liknande föreställningar möter vi än idag hos en del rättslärda. ${ }^{\text {I }}$

3) Flertalet rättslärda utgick från att den dolde imamen, al-Mahdi, mycket snart skulle ge sig till känna och därmed personligen ta hand om alla politiska frågor. De rättslärda såg inte någon anledning till att blanda sig i denna fråga. ${ }^{12}$

4) Utvecklingen av politiska teorier bland shiitiska lärda som dateras till sent I80o-tal och perioden därefter hänger samman med de sociala, strukturella och politiska omvälvningar som shiadominerade samhällen genomgick under denna period. ${ }^{\text {13 }}$

Det som talar för förklaringsmodellerna 2 och 4 är att de tidiga rättslärda, med undantag för ett fåtal, aldrig berör politiken i sina texter. En bra indikation på detta får 
man genom att titta närmare på hur stor andel av de rättslärdas skrifter som ägnades åt denna fråga. Om man följer en tidsaxel från shias tidiga historia fram till vår tid kan man konstatera att utrymmet för dessa frågor växer ju närmare I8oo- och I900-talet vi kommer. Till en början var utrymmet mycket begränsat om inte obefintligt. En framstående rättslärd som Seyyed Murtada (d IoI8) ägnade bara 5 sidor eller I, 6 procent av sin bok «Intisar» till politiken. En annan shiitisk auktoritet, schejk Tousi ( $\mathrm{d}$ IO42) ägnade 74 sidor, eller 2,5 procent av sin bok «al-Mabsout fi fiqh al-imamiyya» åt politik. Knappt tre sekel senare ägnar Allameh Helli (d I308) 55 sidor eller 4,5 procent av sin bok «Tazkira al-fuqaha» åt samma fråga. Den under ı80o-talet verksamme rättslärda schejk Muhammed Hassan Najafi (d I848) ägnar ett helt band på ca 400 sidor av sitt verk «Jawahir al-Kalam» åt denna fråga. ${ }^{\mathrm{I}}$

De shiitiska rättslärdas förhållningssätt till politiska frågor förändrades på I8ootalet när allt fler rättslärda drogs in i diskussionerna kring konstitutionalismens idétradition och den begynnande konstitutionella rörelse som svepte över muslimska länder. Bland de frågor som diskuterades fanns stiftande av grundlag, avskaffande av despoti, införande av parlamentarism, genomförande av allmänna val, att välja eller bli ombud för ett valdistrikt, skrå eller stånd, att skilja mellan de exekutiva, lagstiftande och rättsliga maktinstitutionerna, att införa lagar som skulle skydda grundläggande medborgerliga fri- och rättigheter utan hänsyn till religiös tillhörighet, börd eller social status, att avgöra medborgarnas rätt att få insyn i den politiska makten m.m. . $^{\text {I5 }}$

Men inte heller då var de rättslärda eniga i sina ställningstaganden. Deras reaktioner på dessa frågor kan grovt sett delas in i två kategorier. Den ena utgick från en traditionell hållning som avrådde från inblandning i världsliga frågor, eftersom de ansågs vara ett reserverat område för den dolde imamen. Den andra förordade en modell som gick ut på att bilda en konstitutionell styrelseform under de högsta rättslärdas överinseende. ${ }^{16}$

Den irakiske storayatollan Muhammed Baqer al-Sadr (I935-I980) skriver att under lång tid begränsades utövande av tolkning, ijtihad, bland de shiitiska lärda till det individuella och privata området i människors liv. Politiska frågor lyste med sin frånvaro. Detta berodde enligt al-Sadr på att de rättslärda under lång tid var exkluderade från allt som hade med politiken att göra. De världsliga makthavarna hade en sådan stark maktställning att de inte tillät de rättslärda att blanda sig i dessa frågor. Detta ledde till att ijtihad begränsades till religiösa frågor som framför allt berörde människor på ett individuellt plan. ${ }^{17}$

\section{Från konstitutionalism till radikalism}

Förhållandena förändrades genom påtvingade krig från främmande europeiska stater och att kolonialmakterna fick ett allt starkare grepp om de världsliga makthavarna. Detta ackompanjerades av centralmakternas försvagning i shiadominerade områden. De europeiska köpmännens allt större kontroll över muslimska länders ekonomier ledde till att missnöjet bland köpmännen och samhällets politiska elit växte. Parallellt med detta ledde kontakterna med europeiskt tankegods till att allt fler lät sig påverkas av den konstitutionella idéströmningen med krav på politiska och sociala förändringar i samhället. 
Det som utlöste de skriftlärdas ökade engagemang var att man uppfattade främlingsväldet, de påtvingade krigen och den europeiska kulturens allt större påverkan på det sociala och kulturella livet som ett allvaligt hot mot shiitiska samhällen som skulle bekämpas. Nu när de världsliga makthavarna inte förmådde att stå emot det yttre hotet såg de rättslärda som sin uppgift att använda sig av sitt inflytande för att mobilisera allmänheten mot dessa yttre hot. $^{18}$

Ett flertal shiitiska rättslärda verksamma vid det teologiska centret $\mathrm{i}$ den för shiiter heliga staden Najaf drogs med i den våg som svepte över shiadominerade områden. De engagerade sig i den konstitutionella rörelsen i slutet av i8oo-talet och början av I900-talet. Flera av dem hade sitt ursprung $i$ andra länder som exempelvis Persien.

Vid det osmanska rikets sönderfall bistod shiiterna britterna i störtandet av det osmanska herraväldet över de arabiska regionerna. De hoppades på att få inflytande i den post-osmanska politiska konstellationen. Men när britterna slog ihop de tre gamla osmanska guvernörskapen Mosul, Baghdad och Basra i början av I92o-talet och installerade kung Faisal ur den inflytelserika hashimitiska klanen till regent över den nya staten Irak exkluderades shiiterna från makten.

Iraks moderna historia från I920-talet fram till Bathpartiets maktövertagande i slutet av I960-talet dominerades av brittiskt herravälde, anti-brittiska religiösa och nationalistiska strömningar, militärkupper, uppror bland etniska minoriteter etc. Shiiter och shiitiska rättslärda var en del av denna händelseutveckling. Kännetecknande för landets moderna historia fram till Saddam Husseins era var att shiitiska rättslärda och deras nära anslutna politiska rörelser var exkluderade från makten. Under Saddams tid vid makten hårdnade det politiska förtrycket mot shiiter. En viktig orsak till det var utvecklingen i grannlandet Iran och den islamiska revolutionen där shiitiska rättslärda spelade en central roll. Den islamiska revolutionen i Iran och det nära samröret mellan irakiska och iranska rättslärda blev en inspirationskälla för motståndet mot Bathregimens allt mer hårdnande förtryck mot shiiterna. Saddam Hussein använde detta som en ursäkt för att öka förtrycket mot shiiter. I början av I980-talet lät Saddam avrätta ett flertal framstående shiitiska rättslärda, däribland storayatollan Mohammad Baqer al-Sadr och flera medlemmar ur de ledande rättslärda familjerna eller klanerna al-Sadr och al-Hakim.

Trots Bathregimens hårda framfart mot shiiterna var de shiitiska rättslärda i Irak långt ifrån eniga $i$ frågan om vilken tradition de skulle följa i förhållande till Saddams brutala styre. En del valde politisk avhållsamhet medan andra valde en revolutionär linje för att störta Saddams brutala styre.

En grupp exilirakiska shiitiska skriftlärda som flytt undan Saddam Husseins förföljelser och tagit sin tillflykt till Iran i början av I980-talet valde den revolutionära linjen. Denna fraktion leddes av ayatolla Mohammad Baqer al-Hakim (I939-2003). De bildade The Supreme Council for the Islamic Revolution in Iraq (SCIRI) i början av I980-talet. SCIRI:s grundare hade starka band med iranska shiitiska lärda och hyllade en likartad politisk doktrin som de styrande rättslärda i Iran. ${ }^{\text {I9 }}$

ILLUSTRASJON: ISLAMIC-SHIA-ARTISTS 


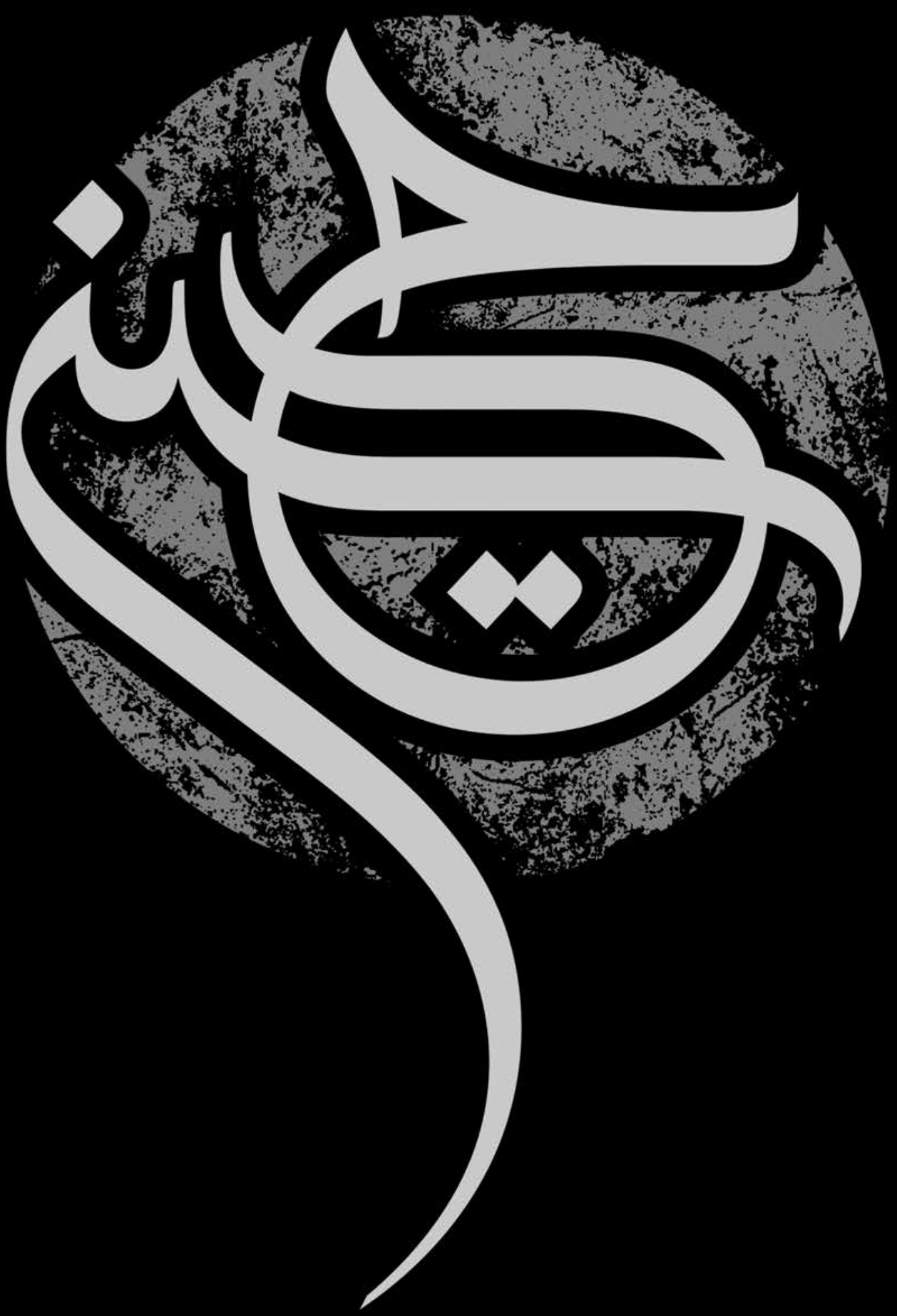


Al-Hakims politiska visioner var knutna till de rådande förhållandena i Irak. Före Saddams fall pläderade han för en revolutionär linje och ville genomdriva en islamisk revolution i Irak för att bilda en islamisk stat. I linje med denna politiska vision bildade SCIRI en väpnad gren i grannlandet Iran och med stöd av den iranska staten, som gick under beteckningen Badr-brigaden. Det revolutionära alternativet framstod för dem som det enda tänkbara alternativet till Saddams brutala diktatur. $^{20}$

\section{Efter den amerikanska invasionen}

Efter den amerikanska invasionen och Saddams fall förespråkade dock al-Hakim ett öppet samarbete med ockupationsmakterna. Han övergav sin tidigare revolutionära linje och valde ett mer realpolitiskt förhållningssätt. Han såg avsättningen av Saddamregimen som de förtryckta shiiternas stora chans att få den politiska makt som de förtjänar när Irak skulle styras genom en representativ styrelseform. Han ville därmed undvika en upprepning av shiiternas, historiskt sett återkommande, exkludering från den politiska makten. SCIRI kom att sitta med i det styrande rådet och senare i den sittande irakiska regeringen.

Som en följd av SCIRI:s kursändring har organisationen bytt namn till The Islamic Supreme Council of Iraq (ISCI). ${ }^{2 \mathrm{I}}$ Parallellt med sin samarbetsvilja gentemot ockupationsmakterna konsoliderade de sin position inne i Irak genom att stärka banden med politiska partier, etniska grupperingar, klanledare och de shiitiska religiösa ledarna i det religiösa centret Hawza. al-Hakim mördades i ett terrordåd 2003, men hans fraktion har hållit fast vid hans linje även efter hans död.
En annan fraktion leddes av storayatollan Sistani. Under Saddams era höll sig denna fraktion borta från politiken med stöd av den shiitiska principen taqiyya. ${ }^{22}$ Fraktionens främsta ansträngningar var under denna period att värna om den shiitiska tron. ${ }^{23}$ Sistani manade sina följeslagare att inte göra motstånd när amerikanska trupper invaderade Irak 2003 med stöd från den shiitiska rättsvetenskapliga principen att "bekämpa det mest ondskefulla med ett nödvändigt ont". ${ }^{24}$ Sistanis uppmaning var inte ett pro-amerikanskt ställningstagande, utan snarare ett första steg $\mathrm{i}$ en förändringsprocess som skulle ändra maktbalansen mellan shiiter och sunniter i det fram till dess av sunniter dominerade Irak. $^{25}$

Sistani-fraktionen ville också undvika en upprepning av shiiternas återkommande exkludering från den politiska makten i

\section{Muqtada al-Sadrs idétradition är en blandning av shiitisk revolutionär ideologi, anti-amerikanism och en portion av arabisk nationalism.}

landet. Sistani, som stöds av en majoritet av shiiterna i Irak, avhåller sig från det dagliga och pågående politiska skeendet, men förbehåller sig rätten att komma med synpunkter i de stora frågorna som bestämmer riktningen för landets utveckling. Hans olika politiska utspel har utgått från såväl religiösa som sekulära demokratiska argument. Detta gäller inte minst i frågor kring den nya irakiska författningen. ${ }^{26}$

Sistani har konsekvent vägrat ta emot amerikanska sändebud men har låtit sin 
son eller andra framstående rättslärda att träffa dessa. ${ }^{27}$ Samtidigt har han inte dragit sig för att rikta skarp kritik mot amerikaner dock utan att gå så långt som ayatolla Khomeini som beskrev USA som den stora satan. Sistani kritiserade amerikanerna för den bristande säkerheten i Irak efter Saddams fall och riktade hård kritik mot amerikanernas planer att utse en kommission bestående av olika irakiska politiker för att skriva ett utkast till den nya irakiska författningen. Han föreslog i stället att de irakiska väljarna skulle välja en församling som skulle ta fram ett utkast till den nya författningen som i sin tur skulle godkännas i en folkomröstning. ${ }^{28}$

Sistani har också gjort direkta ingripanden i den politiska processen. Han tvingade den amerikanske ståthållaren Paul Bremer att dra tillbaka förslaget att det första irakiska valet inte skulle följa en-man-enröst-principen. Efter fleras dagars massdemonstrationer som genomfördes på uppmaning av Sistani drog Bremer tillbaka förslaget. ${ }^{29}$

Sistani har avhållit sig från en kontraproduktiv anti-amerikanism så länge den amerikanska politiken inte varit till uppenbar skada för irakierna i allmänhet och för shiiterna i synnerhet. Han har också välsignat koalitioner av shiitiska politiska partier som bildat gemensam front $\mathrm{i}$ samband med parlamentsval, men samtidigt motsatt sig att shiitiska rättslärda ska sitta med i den irakiska regeringen. Parallellt med detta motarbetade han radikala shiitiska grupperingar som kort efter invasionen krävde att de utländska trupperna skulle dra sig tillbaka från Irak..$^{3^{\circ}}$ Efter de instabila åren som följde på invasionen gick han ut med ett mycket tydligt budskap till det irakiska parlamentet förra året och varnade ledamöterna för att vika sig för USA:s långtgående planer för militär närvaro i Irak efter trupptillbakadragandet. Budskapet var att sätta nationella intressen före USA:s dito i regionen..$^{31}$

Sistani förespråkar vare sig bildandet av en shiitisk stat av iransk modell eller någon diktatur av arabisk modell. Han vill snarare ha en representativ konstitutionell styrelseform som bygger på allmänna val och majoritetsstyre. Shiiterna får stor makt $\mathrm{i}$ denna styrelseform på grund av sin andel av befolkningen, men denna styrelseform ska garantera hela den irakiska befolkningens fri- och rättigheter. ${ }^{22}$ Vidare ska den garantera de shiitiska rättslärda och deras institutioner en sorts suveränitet som skyddar dem från statens inblandning i religiösa frågor. ${ }^{33}$ I denna styrelseform består islams roll i att förse lagstiftarna med normer och vägledning i sociala frågor, ${ }^{34}$ men det är också tänkt att inga lagar ska stiftas i uppenbar strid med islam. ${ }^{35}$

Ytterligare en gruppering i Irak är alSadr-fraktionen som leds av den skriftlärde Muqtada al-Sadr. Fraktionens idétradition är en blandning av shiitisk revolutionär ideologi som ligger nära Khomeinis idétradition, anti-amerikanism och en portion av arabisk nationalism.

Denna blandning gjordes i hopp om att få såväl de shiitiska och sunnitiska arabernas stöd. ${ }^{36}$ al-Sadr-fraktionen motsätter sig de utländska styrkornas närvaro i Irak och dess milis, Mahdi-armén, Jaish al-Mahdi, har varit involverad i flera väpnade duster med ockupationstrupperna. Fraktionen har riktat kritik mot Sistani, al-Hakim och andra shiitiska ledare som visat en mer samarbetsvillig linje och dess mål är att skapa en islamisk stat i Irak. ${ }^{37}$ al-Sadr-fraktionen har trots sin kompromisslösa linje 
mot ockupationsmakten valt att delta i den politiska processen om än med återkommande avbrott.

\section{Avslutning}

Denna studies historiska tillbakablick visar att de centrala tankefigurerna i shiitisk politisk idéhistoria härrör från föreställningarna om den dolde imamen och hans återkomst. Denna föreställning har emellertid inspirerat till olika förhållningssätt till de världsliga makthavarna och då oftast i direkt anslutning till rådande politiska förhållanden. Efter den amerikanska invasionen valde de två främsta politiska fraktionerna bland shiiterna i Irak att följa den klassiska linjen att när en brutal och hårdför makthavare försvinner ska man värna om shiiternas bästa inom ramen för rådande politiska omständigheter. Här finns direkta paralleller till historiska händelser. Dagens shiitiska rättslärda följer ungefär samma handlingsmönster som deras företrädare valde under buyidernas maktövertagande i abbasidernas Baghdad på ıoootalet och efter mongolinvasionen år I258. I båda de historiska fallen hade härskare som utsatt shiiter för hårt förtryck störtats av främmande makter.

Detta mönster upprepas efter den amerikanska invasionen. En brutal och hänsynslös härskare avlägsnades genom krigshandlingar. Shiiterna har på grund av sin majoritet i befolkningsantalet skaffat sig en ledande ställning på den politiska scenen. Någon utveckling i samma riktning som grannlandet Iran var aldrig aktuell, eftersom de ledande rättslärda såg på den iranska modellen som en avvikelse från den klassiska traditionen. Dessutom skulle USA inte gå med på en iransk utveckling samtidigt som de demografiska förutsätt- ningarna var annorlunda och inte gav shiiterna någon absolut majoritet i Irak. Shiiterna har också varit tvungna att förhålla sig till den kurdiska politiska ledningen i norr som vill se en sekulär-federalistisk utveckling i Irak och en sunnitisk minoritet som efter Saddams fall avlägsnats från makten, men som gör allt som står i dess makt för att motarbeta den shiitiska dominansen.

Den politiska utvecklingen efter Saddams fall blev inte heller vad den neokonservativa Bushadministrationen hade önskat sig, det vill säga en sekulär demokrati. I stället kom en regering som domineras av shiiter och som hämtar sin legitimitet hos den hovsamme storayatollan Sistani i det shiitiska religiösa centret i Najaf. $\mathrm{Nu}$ när den amerikanska militära närvaron håller på att avvecklas skulle man kunna förebåda att utvecklingen fortsätter i samma riktning. De fraktioner som förespråkar en revolutionär linje förblir marginella medan grupperingar som följer den klassiska realpolitiska linjen utgör huvuddelen av den shiitiska inriktningen. De olika fraktionerna har en sak gemensam, nämligen att den regeringskoalition som behåller makten i Irak inte utvecklas till en shiafientlig regering. Alltså en regering med stort inslag av diverse shiitiska politiska partier, samtidigt som andra politiska aktörer och krafter finns med i det politiska spelet.

Sett ur ett idéhistoriskt perspektiv tycks de politiska idétraditioner som har vuxit fram hos de shiitiska rättslärda i ljuset av föreställningarna kring den dolde imamen al-Mahdi och hans återkomst, varit ytterst mångfacetterade. Dessa föreställningar har utformats i anslutning till rådande sociala och politiska förhållanden med den gemensamma målsättningen att värna om 
shiiternas väl och ve och de shiitiska religiösa institutionernas suveränitet i väntan på den dolde imamens återkomst. Men när det gäller frågan hur dessa målsättningar ska uppnås har olika fraktioner bildats. En majoritet har valt en realpolitisk tradition som haft successiva förändringar som sin främsta metod. En minoritet har däremot valt en revolutionär linje som prioriterat holistiska förändringar.

\section{$\cdot f \cdot$}

I Aqajari, Hashem: "Farayand-e tahavvull va takamol-e andishe va rafter-e aleman va faqihan-e shii-ya emami" (Förändring och utveckling i de shiitiska tolvimamitiska lärdas tänkande och agerande), Aftab, 2002, s. 60. Se också Sachedina, Abdulaziz Abdulhussein: «The Just Ruler (al-sultan al-'adil) in Shi'ite Islam: The Comprehensive Authority of Juristic in Imamate Jurisprudence», New York. Oxford University press, I988, s. I70.

2 Aqajari: 2002, s. 62.

3 Ibid., s. 64.

4 Seyyed Murtada: «Risala al-amal maa al-sultan» (Boken om samarbete med sultanen), nytryck, vol. 2, Qom: Matbat Sayyid al-shuhada, I987, s. 96-98.

5 Kadivar, Jamileh: «Tahavvule goftemane siyasi-ye shieh dar Iran» (The Development of Shi'ite Political Discourse in Iran), Teheran; Tarhe-e no, 2000, s. 88-89.

6 Ibid.

7 Ibid., s. 99-I02.

8 Kadivar, Mohsen: «Nazariyeha-ye dowlat dar feqh-e shieh» (Teorier om staten i shiitisk rättsvetenskap), Teheran: Nashre ney, I999, s. I3.

9 Hairi, Abdul-Hadi: «Nakhustin rouyarouihaye andishegarane Iran ba do roye-ye tamaddune borjoazi-ye gharb (The Early Encounters of the Iranian Thinkers with the Two-Sided Civilization of Western Bourgeoisie), Teheran: Amir Kabir, I988, s. 374-383.

Io Al-e Seyyed Ghafur, Seyyed Mohsen: Jaygah-e siyasi-ye alem-e dini dar do maktab-e akhbari va usuli (The political position of religious scholars in the two Akhbari and Usuli schools of figh ), Bustan-e ketab publishers: Qom, 2007 , s. 234 .

II Ibid.

I2 Ibid., 235

I3 Ibid.

I4 Amid Zanjani, Abbasali, «Feqhe siyasi» (Politisk rättslära), vol. 2, Teheran: Amir kabir, I989, s. 42-43.
I5 Kadivar: I999, S. 9-I2, I9-2I.

I6 Naini, Mohammad Hussein: «Tanbih al-umma wa tanzîh al-milla» (Samfundets väckelse och nationens renande), 3 uppl., Teheran: Amir kabir, I955, s. 52-55.

I7 Al-Sadr, Seyyed Muhammed Baqer: «Hamrah ba tahavvule ijtihad, persisk översättning av Akbar Thabout, U.o: Roozbeh, I980, s. 2-3.

I8 Ibid.

I9 Nasr, Vali: «The Shia Revival. How Conflicts within Islam Will Shape the Future, London, New York: W. W. Norton \& Company, 2006, s. 192.

$20 \mathrm{http} / /$ isci-iraq.com/home/about-isci/87-the-path-of-thesupreme-council

2I http://isci-iraq.com/home/index.php?option=com_con tent $\&$ view $=$ category\&layout $=$ blog\&id $=57 \&$ Itemid $=69$

22 Den shiitiska principen taqiyya har översatts till förställning. Under shias historia har den kommit att tolkas som en vägledning för shiiter som varit under hårt press från sunniter. Under sådana omständigheter som att shiiternas liv varit i fara kunde de med stöd av denna rättsliga princip förställa sin tro. Taqiyya-principen har också haft politiska dimensioner som inneburit att shiitiska rättslärda inte skyltat med sina politiska föreställningar/ ambitioner för att undvika politisk förföljelse under despotiska härskare som Saddam Hussein.

23 Nasr: 2006 , s. I72.

24 Qouchani, Mohammad: «Se eslam, Maktab-e Najaf, maktab-e Qom, maktab-e Teheran» (Tre islamer. Najafskolan, Qomskolan, Teheranskolan), Teheran: Saraii, 2006, s. 6869 .

25 Nasr: 2006, s. I69-I70

26 Ibid., s. I72.

27 Ibid., s. I75.

28 www.bbc.co.uk/persien/newes/030630_v-sabasistani .shtml. Se också http://www.sistani.org/local.php?mod ules $=$ extra\&eid $=I \&$ nid $=484$, Samt Nasr, 2006 , s. I74.

29 Nasr: 2006, s. I75.

30 Qouchani: 2006, s. 5I-52, 69-70, 7I.

3I http://www.sistani.org/local.php?modules=extra\&eid= I\&nid $=687$

32 Nasr: 2006, s. 176-177.

33 Qouchani: 2006, s. 64-66.

34 Nasr: 2006, s. I73.

35 Ibid., s. I77.

36 Ibid., s. I93.

37 Ibid. 